University of Wollongong

Research Online

Faculty of Social Sciences - Papers (Archive) Faculty of Arts, Social Sciences \& Humanities

2017

The Migration of Horticultural Knowledge: Pacific Island seasonal workers in rural Australia-a missed opportunity?

Olivia V. Dun

University of Wollongong, odun@uow.edu.au

Natascha Klocker

University of Wollongong, natascha@uow.edu.au

Follow this and additional works at: https://ro.uow.edu.au/sspapers

Part of the Education Commons, and the Social and Behavioral Sciences Commons

Research Online is the open access institutional repository for the University of Wollongong. For further information contact the UOW Library: research-pubs@uow.edu.au 


\title{
The Migration of Horticultural Knowledge: Pacific Island seasonal workers in rural Australia-a missed opportunity?
}

\begin{abstract}
In 2012, Graeme Hugo wrote the article 'Migration and Development in Low-income Countries: A Role for Destination Country Policy?' for the inaugural issue of the journal Migration and Development. That article, which continues to be the journal's most viewed work, 1 used the case of Asian and Pacific migration to Australia to question 'whether policies and practices by destination governments relating to international migration and settlement can play a role in facilitating positive developmental impacts in origin communities' (Hugo 2012, 25). The importance of such structural support for development has been underscored, in relation to seasonal worker programs, by growing evidence that their broader development benefits-beyond the household or family unit-cannot be taken for granted (Basok 2000; Craven 2015; Joint Standing Committee on Migration (JSCM) 2016). In this essay we take inspiration from the above-mentioned paper (Hugo 2012), as well as an earlier discussion of 'best practice' temporary labour migration for development (Hugo 2009). Reflecting on Australia's Seasonal Worker Programme (SWP), we make a case for the importance of maximising 'development benefits for origin countries via the transfer of remittances, skills and knowledge' (Bedford et al. 2017, 39; emphasis added). Remittances have been a regular area of policy and research focus. However, less attention has been directed towards the knowledges and skills that move with seasonal workers as part of this circular and temporary migration process-in which the choice is not reduced to one 'between staying or going' (Methmann and Oels 2015, 53), but both staying and going (often repeatedly). Here we draw on our own ongoing research with Pacific Island seasonal workers in Australia's horticultural sector, which points towards the potential for the SWP to facilitate the bi-directional transfer of horticultural knowledges and skills.2 Many seasonal workers have extensive farming experience developed in their countries of origin. Acknowledgement of their farming skills and identities prompts contemplation of how the horticultural knowledge transfers that already happen spontaneously under the SWP could be better supported.
\end{abstract}

\section{Keywords}

migration, horticultural, knowledge:, pacific, missed, island, opportunity?, seasonal, workers, rural, australia-a

\section{Disciplines}

Education | Social and Behavioral Sciences

\section{Publication Details}

Dun, O. \& Klocker, N. (2017). The Migration of Horticultural Knowledge: Pacific Island seasonal workers in rural Australia-a missed opportunity?. Australian Geographer, 48 (1), 27-36. 


\title{
The Migration of Horticultural Knowledge: Pacific Island seasonal workers in rural
} Australia - a missed opportunity?

\author{
Olivia Dun ${ }^{\mathrm{a}}$ and Natascha Klocker ${ }^{\mathrm{b}}$
}

${ }^{\text {a }}$ School of Geography, University of Melbourne, Melbourne, Australia; ${ }^{\mathrm{b}}$ Australian Centre for Cultural Environmental Research, School of Geography and Sustainable Communities, University of Wollongong, Wollongong, Australia

\section{Introduction}

In 2012, Graeme Hugo wrote the article 'Migration and Development in Low-income Countries: A Role for Destination Country Policy?' for the inaugural issue of the journal Migration and Development. That article, which continues to be the journal's most viewed work, ${ }^{1}$ used the case of Asian and Pacific migration to Australia to question 'whether policies and practices by destination governments relating to international migration and settlement can play a role in facilitating positive developmental impacts in origin communities' (Hugo 2012,25). The importance of such structural support for development has been underscored, in relation to seasonal worker programs, by growing evidence that their broader development benefits - beyond the household or family unit - cannot be taken for granted (Basok 2000; Craven 2015; Joint Standing Committee on Migration (JSCM) 2016).

In this essay we take inspiration from the above-mentioned paper (Hugo 2012), as well as an earlier discussion of 'best practice’ temporary labour migration for development (Hugo 2009). Reflecting on Australia's Seasonal Worker Programme (SWP), we make a case for the importance of maximising 'development benefits for origin countries via the transfer of remittances, skills and knowledge’' (Bedford et al. 2017, 39; emphasis added). Remittances have been a regular area of policy and research focus. However, less attention has been directed towards the knowledges and skills that move with seasonal workers as part of this circular and temporary migration process - in which the choice is not reduced to one 
'between staying or going' (Methmann and Oels 2015,53), but both staying and going (often repeatedly).

Here we draw on our own ongoing research with Pacific Island seasonal workers in Australia's horticultural sector, which points towards the potential for the SWP to facilitate the bi-directional transfer of horticultural knowledges and skills ${ }^{2}$. Many seasonal workers have extensive farming experience developed in their countries of origin. Acknowledgement of their farming skills and identities prompts contemplation of how the horticultural knowledge transfers that already happen spontaneously under the SWP could be better supported.

\section{Australia's SWP}

The Pacific Seasonal Worker Pilot Scheme (PSWPS) commenced in 2008 and led to the establishment of the Australian SWP in July 2012 (see Bedford et al. 2017 in this issue for a more detailed overview). The SWP's two key objectives are:

1. 'to contribute to the economic development of participating countries through the provision of employment experience, skills and knowledge transfer, and [through workers] being able to send money back to their home country through remittances' and;

2. 'to assist Australian producers and employers who are unable to source enough local Australian workers to meet their seasonal labour needs by providing access to a reliable seasonal workforce, able to return in future seasons’ (see Durbin in JSCM 2016,5).

When the program was founded, its key initial purpose was to contribute to Australia’s aid program in the Pacific region - addressing labour demands in Australia’s horticultural sector was a secondary purpose (Bedford et al. 2017, this issue; Roddam in JSCM 2016). By way of 
contrast, New Zealand's equivalent Recognised Seasonal Employer (RSE) scheme was implemented in 2007 in direct response to labour shortages in New Zealand's horticultural and viticultural sectors, and consequent demands made by key industry bodies in that country (Bedford et al. 2017, this issue).

The SWP is managed by the Australian federal government, with the Department of Employment as lead administrating department. Governments of the nine participating Pacific Island countries, ${ }^{3}$ and Timor-Leste, make their own arrangements regarding how they wish to recruit workers to participate in the SWP, and enter into Memoranda of Understanding with the Australian government about labour sending and receiving arrangements. Citizens from participating countries can work for up to 6 months in Australia in one of the approved SWP employment sectors, ${ }^{4}$ with the exception of workers from Kiribati, Nauru and Tuvalu who are permitted to remain in Australia for up to 9 months at a time due to higher travel costs (Hugo 2009; Department of Employment 2016). Between December 2009 and June 2016, 12787 seasonal worker places (including 1633 workers who participated in the pilot scheme), had been approved under Australia's SWP (Bedford et al. 2017, this issue). In June 2015, the annual cap on the number of SWP participants was lifted - opening the way for growth. The program had a slow start (Hay and Howes 2012; Doyle and Howes 2015), but the most recent annual intake of 4490 workers (for the year 1 July 2015 - 30 June 2016) has been the highest yet (Bedford et al. 2017, this issue; Howes and Sherrell 2016).

Initial evidence from the multiple submissions and public hearings associated with the recent (2015-16) Australian Parliamentary Inquiry into the SWP, conducted by the Joint Standing Committee on Migration (JSCM), point towards positive changes in the workers' lives. Improvements have occurred primarily through higher income earning opportunities, which 
have contributed to poverty alleviation, housing improvements and enhanced access to education in countries of origin (Australian Council of Trade Unions (ACTU) 2015; Gibson and McKenzie 2011). However, the JSCM (2016) review raised questions regarding the broader development outcomes associated with the SWP, and whether these can be extended beyond the participating households. It concluded '[a]t the time of preparing this report, no verified empirical data was available showing specific linkage between Seasonal Worker Programme remittances and economic development in Pacific communities’ (JSCM 2016,111). Similar limitations have been recognised in relation to the longer-running New Zealand RSE scheme (see Craven 2015) and Canada’s Seasonal Agricultural Worker Programme (see Basok 2000).

The recommendations arising from the JSCM-led inquiry into Australia’s SWP (initiated by the federal Minister for Immigration and Border Protection) focused primarily on the program’s capacity, impact and barriers in relation to Australia’s labour market needs, including the potential for the SWP's expansion beyond the horticultural sector. These labour-focused recommendations suggest a departure from the program’s initial focus on Australia's foreign aid commitments and development outcomes in workers' countries of origin. Howe and Reilly $(2015,3)$ expressed concerns regarding the expansion of the SWP beyond the horticultural sector, which they argued 'places a greater emphasis on its role as a labour market program, and less on the role of assistance to Pacific nations which arises from the special relationship between Australia and Pacific nations’.

\section{Migration and development: the role of seasonal worker programmes}

The link between migration and development has long been an area of scholarly concern. Discussions have generally been 'polarised around two schools of thought' (Hugo 2012,26) - 
one being 'brain drain', which signals a negative development outcome arising from a reduction in human capital in countries of origin; and the second being the sending of remittances by migrant workers. The latter has been viewed positively, especially because remittances reach family members quickly and directly, and can thus have a greater impact on poverty reduction and human well-being than large, bureaucratic development programs and development aid (Skeldon 2008; de Haas 2010).

Complicating the idea of 'brain drain', Hugo (2012) highlighted the positive contributions of diaspora populations to development in countries of origin through remittances, and also through their capacity to act as conduits of information (see also de Haas 2010). Eschewing a purely economic focus, he further noted that migrants 'may return with greater skills and experience than they had before they left and potentially make a greater development contribution' (Hugo 2012,28). While discussing these ideas in the context of skilled migration, Hugo also espoused these sentiments in relation to so-called unskilled and lowskilled migration (Hugo 2009).

Our contention in this essay is that the SWP, as a temporary and circular migration program which legislates return migration, creates important possibilities for knowledge circulation and skills transfer, rather than a one-way 'brain drain'. Similar ideas about the benefits of migration for knowledge transfer have been highlighted by Curtain et al. $(2016,8)$ who recently argued that '[b]oth low-skilled and skilled Pacific migrants can transmit knowledge and skills to their compatriots both upon return and while abroad'. This potential may be particularly strong when participating seasonal workers are involved in horticulture in their countries of origin and destination - as has been the case for the vast majority of seasonal 
workers interviewed as part of our research in Robinvale, in rural north-western Victoria, Australia.

In the remainder of this essay we draw attention to the potential for the SWP to contribute to the transfer of horticultural knowledge and skills, using the case of Samson, ${ }^{5}$ a seasonal worker from Papua New Guinea (PNG). Our key argument is that this example of knowledge transfer was reliant upon individual initiative - and, indeed, the role of migrant agency in the development process has garnered considerable attention in the academic literature (see, for example Faist 2008; Skeldon 2008; Castles 2009;de Haas 2010). Mobility is a standard way in which people exercise agency to improve their livelihoods, and 'the poor' are not merely passive victims of the global capitalist system (Castles 2009; de Haas 2010). However, a focus on development being achieved by migrants themselves arguably diverts attention away from the important role of structural aspects of development policy (Skeldon 2008). The SWP is a highly managed migration program involving heavy engagement by governments, institutions and organisations at both ends (sending and receiving). It thus provides important opportunities to support the transfer of knowledges and skills via structural points of intervention (see also Curtain et al. 2016). In making these observations we acknowledge that the SWP is still in its infancy - thus our intent is to point towards future pathways that could strengthen the program's capacity to achieve its stated development objective.

\section{Farmer-led knowledge transfer through Australia's SWP}

Between February and June 2015 we conducted five focus group interview sessions in Robinvale with 20 horticultural workers participating in the SWP. ${ }^{6}$ These seasonal workers were from PNG (4), Tonga (13) and Kiribati (3) and ranged from first-time program 
participants to those in their seventh program year (given that they had also participated in the pilot scheme). Many of the seasonal workers involved in our study have been involved in horticulture since their childhoods - and maintain subsistence or small-scale commercial farms in their countries of origin, while travelling to Robinvale on an annual basis to work on almond plantations. We feel that the label 'seasonal worker', and notions of unskilled or lowskilled work, does not correctly describe our research participants (nor the work they do in Australia $^{7}$ ). The men to whom we spoke are farmers. We contend that their involvement in the SWP could be productively reframed as a form of 'farmer exchange'.

Our focus here is on Samson, a farm owner in PNG and seasonal worker in Australia. As shown in Box 1, through repeated participation in the SWP since 2011, Samson has made observations and developed skills that have benefited his own noni ${ }^{8}$ plantation in PNG. Both repeat participation and the opportunity to witness practices on Robinvale's almond plantations firsthand appear to have been vital to the success of this knowledge transfer process.

The SWP provides important opportunities for farmer-led knowledge transfers - as seen in the case of Samson's noni plantation - particularly as relationships and conversations develop between seasonal workers and their host country counterparts and employers over areas of common interest. The potential for such exchanges to evolve spontaneously has also been noted in relation to New Zealand's RSE scheme. Bedford et al. (2017, this issue) have described joint ventures between seasonal workers and New Zealand farmers, involving 'agricultural production in Vanuatu (coffee growing on Tanna) and vegetable growing in Samoa’ (Bedford et al. 2017, 48). Also in relation to the RSE, Gibson and McKenzie (2014) found that workers reported gaining pruning skills during their time in New Zealand. 
However, these processes have received little research attention to date. As part of our research project we aim to further document the types of horticultural knowledges and skills that move to and fro, from diverse Pacific countries to Australia and back, through the circular migration flows of the SWP. Prompted by Hugo's $(2012,25)$ call to consider whether the 'policies and practices by destination governments...[are] facilitating positive developmental impacts in origin communities', we now turn to some suggestions for how Australian policies could support horticultural knowledge and skills transfer as an overt component of the SWP.

Box 1. The noni plantation of a PNG seasonal worker $(\mathrm{S}=$ Samson; $\mathrm{O}=$ Olivia).

S: $\quad$ You know most of us we come from agricultural backgrounds...My idea of coming here was...not for money...because I've started a little bit of project [in PNG] because we own the land...I am the landowner...So...when working in the almond farm [in Australia] I've seen how the irrigation system is...The distance how they plant the trees, at least I've learnt. So the previous years when I came and went back [to PNG] I started planning because I'm embarking on a noni project...So previously before coming here...I was planting one metre apart and then the result wasn't good, they [the plants] were too close...I came here [to Robinvale] I learned a lot so I went back [to PNG] and say 'No, this is wrong'. So I have to change the idea of planting the noni, so probably three or four metres apart.

O: $\quad$ And now, how is it?

S: $\quad$ Yeah now it's good. It's growing well. I got a distance where it can really bear big fruit compared to the previous ones where I was like planting them 100 [centi]metres apart and the fruit was not really that big. So when I do my spacing to four metres apart the fruit is really big. And that is the difference...I thank the program, the Australia[n] government, and PNG government, for allowing us to come over here, and just learn something and then take it back and implement it back home.

O: $\quad$ So what is the most valuable thing for you to learn here?

S: $\quad$ Oh I think the most valuable thing is... just looking at how the irrigation system and everything is set up in the farm here. So with that knowledge, if I go back and continue to put my mind to that project, at least I think I should come up with a bigger one and...[become] successful.

O: $\quad$...How important was it that you saw it yourself here in Australia? If somebody came to your farm, your land in PNG and you showed them your noni plants and they told [you] 'Ah you have to make [space] them further apart', if you hadn't 


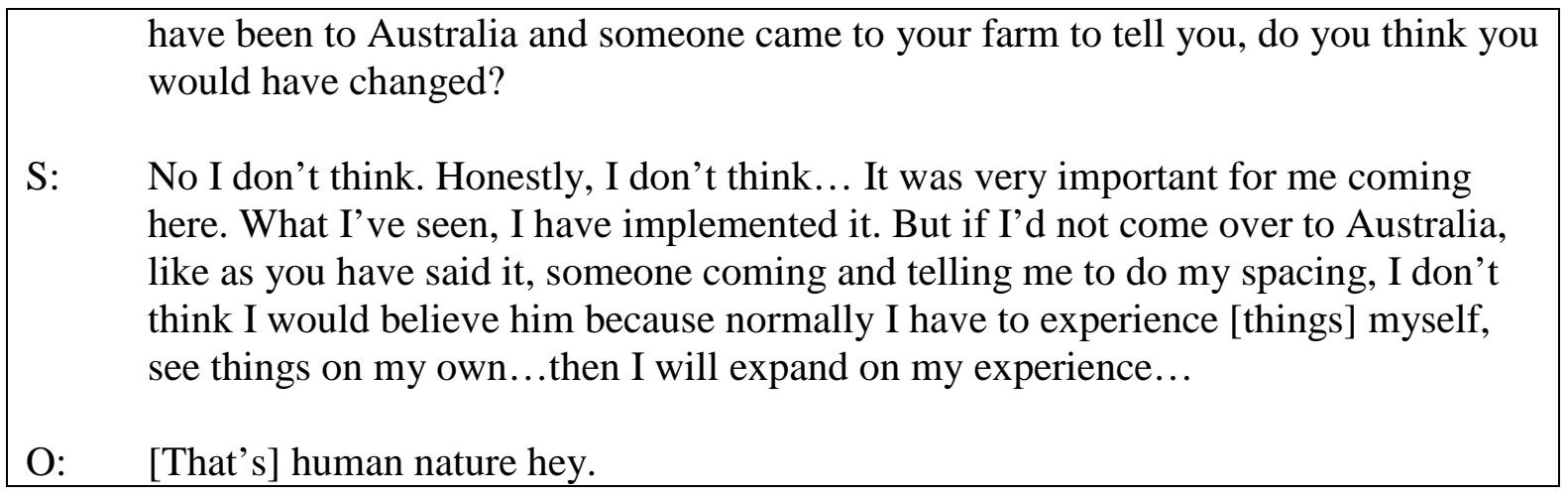

\section{Structural supports to enhance horticultural knowledge transfer via the SWP}

As noted by Hugo (2009,63, 69), amongst the many parameters for best practice in temporary labour migration is the 'provision of training...[which] provides not only a better workforce for employers but the opportunity for social mobility among the migrant workers' and '[t]he adoption of more “development friendly” migration policies by both sending and receiving countries’. Existing reviews into Australia’s SWP, and their resulting reports (discussed below), suggest that seasonal workers’ capacity to contribute to positive development outcomes could be better supported through targeted training programs that are relevant to needs in their origin communities. Through their experiences on Australian farms, some of the seasonal workers we interviewed showed interest in fruit, nut and vegetable growing techniques, grafting practices and greenhouses - and were interested in how these practices might be applied in their home communities. Formalised training opportunities would likely be useful in this regard. In making this argument we do not intend to negate the agency of individual migrants. Seasonal workers who are farmers, like Samson, are already active participants in the knowledge transfer process. However, we are cognisant of broader critiques in the migration-development literature of approaches to development that arguably let governments 'off the hook' through a focus on individual responsibility. Indeed, a recent report into labour mobility (under the World Bank’s Pacific Possible ${ }^{9}$ initiative) asserts that 
both migrant sending and receiving countries need to make improvements with respect to the targeting and delivery of appropriate training (Curtain et al. 2016) - a valid point that we think could be better reflected on with specific reference to the SWP.

The SWP has already incorporated additional training activities, including first aid, English literacy and numeracy, and information technology courses as part of the Add-on Skills Training component of the program (Department of Employment 2015; JSCM 2016). However, the appropriateness of some of these courses has been questioned. As noted by an Approved Employer under the SWP, in a submission to the JSCM-led inquiry, 'some of the courses offered are not very conducive for our employees' learning; e.g. eight hours of numeracy and literacy...provides...I would say no lasting benefits for the person attending the course’ (Golden Mile No. 1 Pty Ltd in JSCM 2016,107). Of particular note - given the heavy horticultural focus of the SWP - is that formally integrated horticultural training appears to have been somewhat neglected. This gap was noted by Queensland TAFE, in an undated submission to the Parliamentary Inquiry into the SWP (see JSCM 2016). The submission emphasised the role that such training could play in enhancing the knowledge transfer processes and development objectives of the program:

Of more interest is how any training that is provided in Australia to the seasonal workers transfers into growing workforce capability in the source countries. The skilling of the workers and the encouragement to share their skills when they return to their source country could be highly beneficial in raising the level of agricultural output and subsequent economic opportunity for the workers and their families. TAFE Queensland is of the view that extension of the SWP should include some base level training that is not dissimilar to the supported training for new migrants to Australia. 
It would incorporate literacy and numeracy training as well as some of the training required for the job they are coming for (Queensland TAFE n.d., 13; emphasis added)

In its submission, Queensland TAFE (n.d.) also highlighted its affiliation with the Australian Pacific Technical College (APTC). The APTC is an Australian government initiative managed, as part of the Australian aid program, through the Department of Foreign Affairs and Trade (DFAT) (APTC 2016). It delivers technical and vocational training for Australianstandard qualifications to course participants across 14 Pacific Island countries (DFAT n.d.). Such training would be well suited to the circular nature of seasonal worker movement - but there is a key gap in its capacity to add value to the SWP both because it currently does not offer training in horticulture, and because the APTC has not explicitly focused on training SWP migrants. This is a missed opportunity, both in terms of supporting the development outcomes of the SWP and in terms of ensuring that Australian employers have access to workers trained in the skills that they need. Better alignment between the SWP and APTC is the type of structural intervention that could support 'best practice' in training and skills transfer associated with temporary labour migration schemes. Knowing that SWP migrants will generally return to their home countries may also go some way to allaying concerns expressed by some Pacific Island governments that trained residents will migrate to highincome countries (Curtain et al. 2016). And for seasonal migrants who are farmers, like Samson, such connections could provide important support for - and formal recognition of the knowledge transfer processes in which they are already engaged. While APTC training takes place 'in country’, Samson’s story underscores the importance of firsthand experience on Australian farms. Better links between the APTC and SWP could therefore also benefit the development outcomes associated with the former. 
Finally, while not the explicit focus of this essay, efforts to facilitate and support knowledge transfer as part-and-parcel of the SWP should also pay attention to the potential for bidirectional knowledge transfer - that is, the incorporation of seasonal workers' knowledge into the Australian context both in and beyond their workplaces. Our broader research project has documented examples of informal horticultural knowledge exchanges between Pacific Island migrants and Australian residents and farmers in rural north-western Victoria. As proposed by Queensland TAFE (n.d.,10), it is important to 'recognise the skills that the migrant labour force brings and the knowledge exchange that occurs as a result of informal interaction during the job’. Acknowledging that many seasonal workers involved in the SWP are farmers - and thus re-envisioning aspects of the program as a form of 'farmer exchange' - could be an important first step.

\section{Concluding remarks}

Remittances play a vital role in supporting seasonal workers' households in countries of origin. However, we see considerable potential in the SWP for a complementary focus on the exchange of horticultural knowledge and skills. Evidence is beginning to emerge - including through our own ongoing research - of the skilfulness of seasonal migrant workers, who have shown a capacity to transfer practices witnessed on Australian farms onto their own farms in countries of origin. In this essay, we have argued that horticultural knowledge and skills transfer ought to be more formally integrated into the SWP, especially in situations where the seasonal workers are involved in similar activities in countries of origin and destination.

Taking inspiration from Graeme Hugo, we have made a case that Australia's SWP - which already involves migrants who are highly practised farmers - provides an important opportunity to look beyond labour and remittances. Through this intervention we also seek to counter worrying trends that have emerged from the labour (rather than development) focus 
of the Australian Parliamentary Inquiry into the SWP. At a time when the program is

increasingly being framed in terms of Australian labour shortages and needs (i.e. what

migrants workers can do for 'us'), it is worth drawing attention back to the SWP's original

emphasis on foreign aid objectives in the Pacific.

\footnotetext{
${ }^{1}$ See Irudaya Rajan's (2015) editorial tribute to Graeme Hugo in Migration and Development.

${ }^{2}$ This research is being undertaken as part of an Australian Research Council Discovery Project (DP140101165), on which Professors Lesley Head, Gordon Waitt and Heather Goodall are co-investigators.

${ }^{3}$ Fiji, Kiribati, Nauru, Papua New Guinea, Samoa, Solomon Islands, Tonga, Tuvalu and Vanuatu.

${ }^{4}$ Initially the PSWPS and SWP applied only to Australia's horticultural sector where seasonal workers are hired to carry out tasks such as picking, packing, thinning and pruning horticultural produce (such as fruits, vegetables and nuts). However, in June 2015, along with the release of the Commonwealth of Australia's White Paper on Developing Northern Australia 'Our North, Our Future', the SWP was extended to incorporate cane, cotton and aquaculture, the accommodation sector (only in certain Australian locations) and the tourism industry (in Northern Australia only) (JSCM 2016). In February 2016 there was further expansion of the SWP to other areas of the agricultural sector including dairying, livestock, hatcheries as well as broadacre and mixed farming enterprises (JSCM 2016).

${ }^{5}$ This is a pseudonym.

${ }^{6}$ These participants were working under the labour sub-contractor, Tree Minders, a family-owned labour hire company supplying labour for the horticulture sector. Tree Minders helped to facilitate our recruitment of interview participants.

${ }^{7}$ This assertion matches recent calls from Australian fruit and vegetable growers, the National Farmers Federation and the Primary Industries Skills Council to recognise the complexity of intensive horticulture farming and the need for 'skilled horticultural workers' (Martin 2013, n.p.).

${ }^{8}$ The noni plant 'Morinda citrifolia L (Noni) has been used in folk remedies by Polynesians for over 2000 years, and is reported to have a broad range of therapeutic effects, including antibacterial, antiviral, antifungal, antitumor, antihelmin, analgesic, hypotensive, anti-inflammatory, and immune enhancing effects' (Wang et al. 2002,1127).

9 'Pacific Possible is focused on the genuinely transformative opportunities that exist for Pacific Island countries over the next 25 years' in recognition that 'Pacific island countries face unique development challenges'. It seeks to uncover such opportunities by commissioning new research that 'aims to answer the question: What is possible in the Pacific?’ (http://www.worldbank.org/en/country/pacificislands/brief/pacific-possible).
} 


\section{Acknowledgements}

Our thanks go to the Pacific Island seasonal workers who have given us their time and shared their stories. We are very grateful to Alf Fangaloka of Tree Minders, Robinvale, for facilitating access to Pacific Island seasonal workers. Professor Lesley Head's encouragement to think differently about people's relationships with nature has been influential for our thinking in this essay. We also acknowledge research assistance provided by Ikerne Aguirre Bielschowsky. Finally, our deepest gratitude to Graeme Hugo for his work on migration and development and best practice for temporary labour migration that has provided much guidance, structure and direction regarding points of intervention for improving development outcomes.

\section{Disclosure statement}

No potential conflict of interest was reported by the authors.

\section{ORCID}

Olivia Dun http://orcid.org/0000-0002-3660-6827

Natascha Klocker http://orcid.org/0000-0001-7526-3292

\section{References}

ACTU (Australian Council of Trade Unions). 2015. “ACTU Submission to Parliamentary Inquiry into the Seasonal Worker Program” (Inquiry into the Seasonal Worker Programme: Submission 19). ACTU, Melbourne.

http://www.aph.gov.au/Parliamentary_Business/Committees/Joint/Migration/Seasonal_Work er_Programme/Submissions

APTC (Australia Pacific Training College). 2016. “"About Us Australia-Pacific Technical College, Suva.” https://www.aptc.edu.au

Basok, T. 2000. "Migration of Mexican Seasonal Farm Workers to Canada and Development: Obstacles to Productive Investment.” International Migration Review 34 (1): 79-97.

Bedford, R., C. Bedford, J. Wall, and M. Young. 2017. "Managed Temporary Labour Migration of Pacific Islanders to Australia and New Zealand in the Early Twenty-first Century.” Australian Geographer 48 (1): 35-57.

Castles, S. 2009. "Development and Migration-Migration and Development: What Comes First? Global Perspective and African Experiences.” Theoria, 56 (121): 1-31.

Craven, L. 2015. “Migration-affected Change and Vulnerability in Rural Vanuatu.” Asia Pacific Viewpoint 56 (2): 223-236.

Curtain, R., M. Dornan, J. Doyle, and S. Howes. 2016. "Labour Mobility: The Ten Billion Dollar Prize.” Pacific Possible Development Policy Centre, The Australian National 
University, Canberra and The World Bank, Washington D.C.

http://www.worldbank.org/en/country/pacificislands/brief/pacific-possible

Department of Employment. 2015. Add-on Skills Training Fact Sheet (version 19 June 2015).

Canberra: Department of Employment.

https://docs.employment.gov.au/system/files/doc/other/06-

15_seasonal_worker_programme_aost_factsheet.pdf

Department of Employment. 2016. Seasonal Worker Programme. Canberra: Department of Employment. https://www.employment.gov.au/seasonal-worker-programme

DFAT (Department of Foreign Affairs and Trade). n.d. "Joint Standing Committee on Migration Inquiry into the Seasonal Worker Programme: Submission of the Department of Foreign Affairs and Trade” (Inquiry into the Seasonal Worker Programme: Submission 37). Department of Foreign Affairs and Trade, Canberra.

http://www.aph.gov.au/Parliamentary_Business/Committees/Joint/Migration/Seasonal_Work er_Programme/Submissions

Doyle, J. and S. Howes. 2015. Australia's Seasonal Worker Programme: Demand-side Constraints and Suggested Reforms. Washington, DC: World Bank Group.

Faist, T. 2008. "Migrants as Transnational Development Agents: An Inquiry into the Newest Round of the Migration-Development Nexus.” Population, Space and Place 14 (1): 21-42.

Gibson, J., and D. McKenzie. 2011. “Australia's PSWPS: Development Impacts in the First Two Years.” Asia Pacific Viewpoint 52 (3): 361-370.

Gibson, J., and D. McKenzie. 2014. "The Development Impact of a Best Practice Seasonal Worker Policy.” Review of Economics and Statistics 96 (2): 229-243.

de Haas, H. 2010. “Migration and Development: A Theoretical Perspective.” International Migration Review 44 (1): 227-264.

Hay, D. and S. Howes. 2012. “Australia’s Pacific Seasonal Worker Pilot Scheme: Why has Take-up been so Low?” [Blog], Devpolicy, the Development Policy Centre, Australian National University Canberra. http://devpolicy.org/australias-pacific-seasonal-worker-pilotscheme-why-has-take-up-been-so-low20120404/

Howe, J., and A. Reilly. 2015. "Submission to the Joint Standing Committee on Migration inquiry into the Seasonal Worker Programme” (Inquiry into the Seasonal Worker Programme: Submission 36). Public Law and Policy Research Unit, University of Adelaide, Adelaide.

http://www.aph.gov.au/Parliamentary_Business/Committees/Joint/Migration/Seasonal_Work er_Programme/Submissions 
Howes, S., and H. Sherrell. 2016. “Seasonal Worker Program Grows by 50 Per cent” [Blog], Devpolicy, the Development Policy Centre, Australian National University Canberra. http://devpolicy.org/seasonal-worker-program-grows-50-per-cent-20161116/

Hugo, G. 2009. “Best Practice in Temporary Labour Migration for Development: A Perspective from Asia and the Pacific.” International Migration 47 (5): 23-74.

Hugo, G. 2012. "Migration and Development in Low-income Countries: A Role for Destination Country Policy?” Migration and Development 1 (1): 24-49.

Irudaya Rajan, S. 2015. "Migration and Development: In Pursuit of Unlimited Debates.” Migration and Development 4 (1): 1-3.

JSCM (Joint Standing Committee on Migration) 2016. Seasonal Change: Inquiry into the Seasonal Worker Programme. Canberra: The Parliament of the Commonwealth of Australia.

Martin, S. 2013. “Lettuce Use Foreign Skills to Grow.” The Australian, March 1.

http://www.theaustralian.com.au/national-affairs/industrial-relations/lettuce-use-foreignskills-to-grow/story-fn59noo3-1226587987585

Methmann, C., and A. Oels. 2015. “From 'Fearing' to 'Empowering' Climate Refugees: Governing Climate-induced Migration in the Name of Resilience.” Security Dialogue 46 (1): 51-68.

Queensland TAFE. n.d. “TAFE Queensland's Response to the Inquiry into the Seasonal Worker Programme” (Inquiry into the Seasonal Worker Programme: Submission 27). http://www.aph.gov.au/Parliamentary_Business/Committees/Joint/Migration/Seasonal_Work er_Programme/Submissions

Skeldon, R. 2008. "International Migration as a Tool in Development Policy: A Passing Phase?” Population and Development Review 34 (1): 1-18.

Wang, M-Y., B.J. West, C.J. Jensen, D. Nowicki, C. Su, A.K. Palu, and G. Anderson. 2002. "Morinda Citrifolia (Noni): A Literature Review and Recent Advances in Noni Research." Acta Pharmacologica Sinica 23 (12): 1127-1141. 